\title{
Testicular Cancer Serum Markers Test Result
}

National Cancer Institute

\section{Source}

National Cancer Institute. Testicular Cancer Serum Markers Test Result. NCI Thesaurus.

Code C111067.

A laboratory test result in which markers for testicular cancer are tested in a blood sample for staging purposes. 